\title{
Characterization of smectite and illite by FTIR spectroscopy of interlayer $\mathrm{NH}_{4}^{+}$ cations
}

\author{
J. PIRONON ${ }^{1} *$, M. PELLETIER ${ }^{2}$, P. DE DONATO ${ }^{2}$ AND R. MOSSER-RUCK ${ }^{1}$ \\ ${ }^{1}$ UMR G2R, Université Henri Poincaré, BP 239, 54506 Vandouvre-lès-Nancy, France, and ${ }^{2}$ Laboratoire \\ Environnement et Minéralurgie, INPL-CNRS UMR 7569, BP 40, 54501 Vandouvre-lès-Nancy, France
}

(Received 10 October 2001; revised 18 November 2002)

\begin{abstract}
FTIR spectroscopy has been applied to $\mathrm{NH}_{4}^{+}$-exchanged dioctahedral clay minerals to determine the molecular environment of $\mathrm{NH}_{4}^{+}$and to quantify $\mathrm{N}$ concentration. FTIR under vapourpressure control, coupled with heating and freezing treatments has shown that $\mathrm{NH}_{4}^{+}$ion symmetry varies with the nature of clay minerals. $\mathrm{NH}_{4}^{+}$has a perfect tetrahedral symmetry in hydrated or dehydrated smectites and belongs to the $T_{\mathrm{d}}$ symmetry group. The $\mathrm{NH}_{4}^{+}$-bending vibration is centred at 1450 and $1425 \mathrm{~cm}^{-1}$.

The $\mathrm{Si}^{4+}-\mathrm{Al}^{3+}$ substitution in dioctahedral clay minerals induces the loss of symmetry elements of the $\mathrm{NH}_{4}^{+}$tetrahedron which acquires a $C_{2 \mathrm{v}}$ symmetry. As a consequence, the $T_{\mathrm{d}}-C_{2 \mathrm{v}}$ transition can be used to characterize the smectite-illite transition. Quantification of $\mathrm{NH}_{4}^{+}$content per half unit cell is provided by $n_{\mathrm{NH}_{4}}=k\left[\mathrm{NH}_{4}\right] /[\mathrm{OH}]$ where $\left[\mathrm{NH}_{4}\right] /[\mathrm{OH}]$ is the band area ratio of the $\mathrm{NH}_{4}^{+}$-bending vibration to the $\mathrm{OH}$-stretching vibration. $k=1.1$ for hydrated smectite, 0.9 for dehydrated smectite and 0.8 for illite or tobelite. The bending vibration of $\mathrm{NH}_{4}^{+}$is chosen for the calculation because it is not affected by superimposed contributions.
\end{abstract}

KEYWORDS: ammonium, smectite, illite, tobelite, IR spectroscopy, hydration.

In subsurface geological environments, the presence of $\mathrm{NH}_{4}^{+}$ions is generally explained as resulting from deamination of organic matter (Hunt, 1979; Tissot \& Welte, 1984; Williams \& Ferrell, 1991). However, the $\mathrm{NH}_{4}^{+}$ion is also detected in metamorphic, igneous and volcanic systems. In view of its stability field, the $\mathrm{NH}_{4}^{+}$ion can be used as a pH-Eh marker: it is stable at low $\mathrm{pH}$ and $\mathrm{Eh}$ and therefore is commonly encountered in sedimentary basins. Due to both its organic origin (Boudou et al., 1984; Williams et al., 1989; Williams \& Ferrell, 1991; Barth et al., 1996) and pH-Eh stability field (Grishina et al., 1998) analyses of $\mathrm{NH}_{4}^{+}$ions play an important role in reconstructing the sedimentary, diagenetic and metamorphic evolution of rocks.

* E-mail: jacques.pironon@g2r.uhp-nancy.fr DOI: $10.1180 / 0009855033820089$
$\mathrm{NH}_{4}^{+}$has an ionic radius of $1.43 \AA$. As this value is close to the ionic radius of $\mathrm{K}^{+}(1.33 \AA)$ (Lindgreen, 1994), $\mathrm{NH}_{4}^{+}$often substitutes for $\mathrm{K}$ in minerals (Bos et al., 1988; Bastoul et al., 1993). Salts (sylvite, carnallite) and silicates (feldspar, mica, clay minerals) are the most common $\mathrm{NH}_{4}^{+}$ bearing minerals, often found in evaporitic and clastic systems sometimes affected by metamorphism (Williams et al., 1989; Pironon et al., 1995a,b).

In layered minerals, $\mathrm{NH}_{4}^{+}$ions are usually located in the interlayer space as charge-compensating cations. Such a situation is encountered in nature for micas (biotite, muscovite) (Vedder, 1965; Bos et al., 1988; Bastoul et al., 1993; Higashi, 2000) and swelling clay minerals (vermiculite, smectite) (Mortland et al., 1963; Šuchá et al., 1994; Lindgreen, 1994; Schroeder and Ingall, 1994; Schroeder \& McLain, 1998). Ammoniun ions have 
a tetrahedral symmetry with a central $\mathrm{N}$ atom surrounded by four $\mathrm{H}$ atoms. For constant $\mathrm{N}-\mathrm{H}$ bond length and $\mathrm{H}-\mathrm{N}-\mathrm{H}$ angle, ammonium belongs to the $T_{\mathrm{d}}$ symmetry group. Due to this $T_{\mathrm{d}}$ symmetry, the mid-infrared (IR) spectrum exhibits two main absorption bands: a triply degenerate bending-vibration band located between 1400 and $1500 \mathrm{~cm}^{-1}$ and a triply degenerate stretching vibration located at $\sim 3300 \mathrm{~cm}^{-1}$.

According to Chourabi \& Fripiat (1981), the IR spectra of $\mathrm{NH}_{4}^{+}$-smectite is affected by increasing $\mathrm{Al}$ for $\mathrm{Si}$ substitution in the tetrahedral sheet. Indeed, for increasing $\mathrm{Si}^{4+}-\mathrm{Al}^{3+}$ substitution, the $\mathrm{NH}_{4}^{+}$ion is increasingly distorted, which should result in a change from the $T_{\mathrm{d}}$ symmetry to the $C_{3 \mathrm{v}}$ symmetry. Such lowering of $T_{\mathrm{d}}$ symmetry was described by Casal et al. (1984) in the case of $\mathrm{NH}_{4}^{+}$-exchanged montmorillonite (Table 1). This symmetry change results in the loss of three $C_{3}, C_{2}$ and $S_{4}$ axes and three planes of symmetry (Herzberg, 1947). This work aims to demonstrate that, on the basis of these symmetry changes, IR spectroscopy can be used to characterize the smectite-illite transition and it complements X-ray diffraction (XRD) studies. More precisely, the main objectives of this work are (1) to characterize the symmetry and molecular environment of $\mathrm{NH}_{4}^{+}$ions using IR spectroscopy, and (2) to propose a quantification procedure for $\mathrm{N}$ analysis of layered minerals. To achieve the first objective, we characterized in detail the effect of interlayer spacing and water adsorption on the FTIR spectrum of $\mathrm{NH}_{4}^{+}$-exchanged clays. The second objective was the development of the feasibility study by Shigorova (1982) who was the first to show that IR spectroscopy can provide a quantification of the $\mathrm{NH}_{4}$ content of micas.

\section{ANALYTICAL PROCEDURES}

Two different analytical procedures were applied to characterize smectite, illite and tobelite using FTIR spectroscopy.

The Fourier transform spectrometer used is a Bruker IFS 55 coupled with two different sampling devices: (1) A Bruker microscope which collects the IR beam with cassegrain objectives. Analysis of clay films deposited on a $\mathrm{CaF}_{2}$ disk was carried out by transmission, using a circular diaphragm with a $60 \mu \mathrm{m}$ diameter aperture in the image plane and a MCT detector. Spectra of atmospheric $\mathrm{CO}_{2}$ and $\mathrm{H}_{2} \mathrm{O}$ were recorded independently for subtraction purposes. Optical microscopy allows visual control of the purity of the area studied (i.e. the absence of mineral or organic contamination). A Linkam FT-IR 600 microthermometric stage was also adapted to the Bruker microscope to record IR spectra at various temperatures. Such a set-up allows us to record IR spectra from $-196^{\circ} \mathrm{C}$ (liquid nitrogen temperature) to $+600^{\circ} \mathrm{C}$. To record transmission IR microspectroscopy spectra at various temperatures, some specific adaptations are required: IR transparent windows $\left(\mathrm{CaF}_{2}\right.$ or $\left.\mathrm{BaF}_{2}\right)$ are used to replace all glass slides. In the case of clay minerals, the use of FTIR microspectrometry at various temperatures has several advantages. Indeed, at very low temperatures the IR absorption bands narrow, which facilitates band assignment and decomposition procedures. Variable-temperature studies also provide some insight into the various populations of water molecules, more or less firmly adsorbed on the clay surfaces, whereas the use of high temperatures permit study of water release and the associated structural changes. (2) In order to study

TABLE 1. Wavenumbers of normal modes of vibration of $\mathrm{NH}_{4}^{+}$with $T_{\mathrm{d}}$ or $C_{3 \mathrm{v}}$ symmetry.

\begin{tabular}{ccc}
\hline $\begin{array}{c}\text { Symmetry } \\
\text { IR vibration }\end{array}$ & $\begin{array}{c}T_{\mathrm{d}} \\
\text { wavenumber }\left(\mathrm{cm}^{-1}\right)\end{array}$ & $\begin{array}{c}C_{3 \mathrm{v}} \\
\text { wavenumber }\left(\mathrm{cm}^{-1}\right)\end{array}$ \\
\hline$v_{1}$ & $3040^{1}$ & $v_{1} 3030^{3}-3070^{4}$ \\
$v_{2}+v_{4}$ & $3053^{2}$ & Not observed \\
$v_{2}$ & $1680^{1}-1649^{2}$ & $v_{3 \mathrm{a}}-v_{3 \mathrm{bc}} 3195^{4}-3250^{3}$ \\
$v_{3}$ & $3145^{1,2}$ & $v_{4 \mathrm{a}}-v_{4 \mathrm{bc}} 1430^{3,4}$ \\
$v_{4}$ & $1400^{1}-1404^{2}$ & \\
\hline
\end{tabular}

(1) from Nakamoto (1963); (2) for $\mathrm{NH}_{4} \mathrm{Cl}$ at $22^{\circ} \mathrm{C}$ from Morgan et al. (1957);

(3) for smectites from Chourabi \& Fripiat (1981); (4) for montmorillonites from Casal et al. (1984). 
TABLE 2. Structural formulae of layered minerals (average of 10 analyses). Half-unit-cell formulae were calculated from electron microprobe analysis, considering all $\mathrm{Fe}$ to be $\mathrm{Fe}^{3+}$, and from FTIR analysis for $\mathrm{NH}_{4}$.

\begin{tabular}{lccccccccccc}
\hline & $\mathrm{Si}^{\mathrm{IV}}$ & $\mathrm{Al}^{\mathrm{IV}}$ & $\mathrm{Al}^{\mathrm{VI}}$ & $\mathrm{Fe}^{\mathrm{VI}}$ & $\mathrm{Mg}^{\mathrm{VI}}$ & $\mathrm{O}$ & $\mathrm{OH}$ & $\mathrm{K}$ & $\mathrm{Ca}$ & $\mathrm{Na}$ & $\mathrm{NH}_{4}$ \\
\hline $\mathrm{SmW}$ & 3.91 & 0.09 & 1.53 & 0.20 & 0.29 & 10 & 2 & 0.01 & 0.08 & 0.13 & 0.00 \\
$\mathrm{NH}_{4}$-SmW & 3.87 & 0.13 & 1.57 & 0.19 & 0.26 & 10 & 2 & 0.00 & 0.00 & 0.00 & 0.31 \\
Illite Netherlands & 3.36 & 0.64 & 1.65 & 0.11 & 0.24 & 10 & 2 & 0.45 & 0.01 & 0.06 & 0.33 \\
Tobelite & 3.17 & 0.83 & 1.97 & 0.03 & 0.05 & 10 & 2 & 0.19 & 0.00 & 0.00 & 0.53 \\
& & & & & & & & & & & \\
\hline
\end{tabular}

SmW: initial smectite from Wyoming, $\mathrm{NH}_{4}-\mathrm{SmW}$ : smectite from Wyoming exchanged with $\mathrm{NH}_{4}$. Tobelite formula is from Higashi (1982).

possible changes in the IR vibrations of $\mathrm{NH}_{4}^{+}$ions and hydration water molecules, IR spectra were obtained with a special lab-built IR cell with controlled water pressure (Pelletier et al., 1999). When combined with water adsorption measurement and XRD studies under controlled water pressure, the use of such a set-up allows us to obtain very valuable information on the status of water in layered materials (Pelletier et al., 1999; EypertBlaison et al., 2001). The sample is a clay film, deposited on a gold grid, and placed on the IR beam before a DTGS detector. Two $\mathrm{CaF}_{2}$ windows close the cell. The sample is maintained under vacuum at $10^{-6}$ Torr for 10 days in order to acquire a good reference spectrum $\left(P / P_{0}=0\right)$. The film is kept at $30^{\circ} \mathrm{C} \pm 0.1^{\circ} \mathrm{C}$ and the control of the relative water vapour pressure in the cell $\left(P / P_{0}\right)$, is obtained by setting the temperature of a water liquid source connected to the cell. By controlling its temperature between -20 and $+27.9^{\circ} \mathrm{C}\left( \pm 0.1^{\circ} \mathrm{C}\right)$, a $P / P_{0}$ range from 0.024 to 0.85 can be investigated. The equilibrium time for each water vapour relative pressure $\left(P / P_{0}\right)$ varies between 24 and $96 \mathrm{~h}$.

The spectral resolution is $4 \mathrm{~cm}^{-1}$ and the recording time is $1 \mathrm{~min}$. Spectra are presented in absorbance units between 4000 and $1200 \mathrm{~cm}^{-1}$. Bands located below $1200 \mathrm{~cm}^{-1}$ are not taken into account because of detector saturation in the region of Si-O stretching and absorption of $\mathrm{CaF}_{2}$ windows below $800 \mathrm{~cm}^{-1}$. Each spectrum was processed using the OPUS program ( (C) Bruker). The integrated intensities of $\mathrm{OH}$-stretching bands and $\mathrm{H}_{2} \mathrm{O}-$ and $\mathrm{NH}_{4}$-bending bands were calculated. Peak areas were calculated using various baseline corrections (linear or polynomial) and a standard deviation of $3 \%$ was thus determined. $\mathrm{NH}_{4}$-bending bands were decomposed after baseline correction using the Levenberg-Marquard algorithm and mixed Lorentzian-Gaussian curves.

\section{SA MPLES}

Three different samples were used for this study. They cover the dioctahedral range of layer charge from smectite to muscovite, and are composed of particles $<2 \mu \mathrm{m}$ in size.

Ammonium-smectite was prepared from a natural Ca-Na-smectite from Wyoming. The initial structural formula was determined by electron microprobe and ICP-MS analysis (Table 2). $10 \mathrm{~g}$ of smectite were placed in $100 \mathrm{ml}$ of $1 \mathrm{M} \mathrm{NH}_{4} \mathrm{Cl}$ aqueous solution at room temperature and stirred for $2 \mathrm{~h}$. After solidliquid separation the solution was renewed, and that procedure was repeated three times. Electron microprobe and ICP-MS analyses showed that octahedral sites are not strongly affected by such exchange treatment and that $\mathrm{K}, \mathrm{Ca}$ and $\mathrm{Na}$ are completely released from the interlayer space of smectite. The $\mathrm{NH}_{4}$ content was deduced from FTIR analysis, as explained later. X-ray diffraction studies revealed that the sample preparation did not cause any crystallographic modifications.

The illite sample used comes from a shale of the Namurian-Dinantian boundary, located at the

TABLE 3. Assignments of mid-IR vibration bands of $\mathrm{NH}_{4}$-clays (Van der Marel \& Beutelspacher, 1976; Chourabi \& Fripiat, 1981).

\begin{tabular}{cc}
\hline Wavenumber $\left(\mathrm{cm}^{-1}\right)$ & Assignment \\
\hline 3630 & $\mathrm{OH}$ from octahedral sites \\
& (stretching) \\
$3425-2830$ & $\mathrm{H}_{2} \mathrm{O}$ and $\mathrm{NH}_{4}$ (stretching) \\
1846 & $\mathrm{SiO}$ (combination) $_{1633} \mathrm{H}_{2} \mathrm{O}$ (bending) \\
$1450-1427$ & $\mathrm{NH}_{4}$ (bending) \\
$1167-1027$ & $\mathrm{SiO}$ (stretching) $_{919-798}$ \\
& $\mathrm{OH}$ from octahedral sites \\
& (bending) \\
\hline
\end{tabular}


marine-lacustrine transition in the Netherlands. It was sampled from a well in the Geverik area at a depth of $963 \mathrm{~m}$. This series, $400 \mathrm{~m}$ thick, is marked by a zonation of marine black shales and limestones. Illite is associated with chlorite, organic matter, detrital micas, framboidal pyrite, calcite and dolomite. X-ray diffraction patterns of the clay fraction reveal an illitic composition mixed with 5\% of chlorite. The widths at half maximum of the (001) diffraction peak for illite are 1.2 and $0.8 \AA$, for the normal and glycolated diffractograms, respectively. These differences can be explained by the presence of either poorly crystalline illite or interstratified minerals, or by the occurrence of $\mathrm{NH}_{4}^{+} / \mathrm{K}$ in illite. The presence of $\mathrm{NH}_{4}$ was confirmed by FTIR analysis (Table 2). The sample contains $>5 \%$ carbon and the reflectance of vitrinite is near $3.7 \%$.

Tobelite is an $\mathrm{NH}_{4}$ muscovite, from the Tobe area (Japan) described and provided by $\mathrm{Dr} \mathrm{S}$. Higashi. Ammonium-bearing dioctahedral micas are associated with quartz and graphite in a hydrothermally altered biotite andesite dyke of Miocene age (Higashi, 1982). Tobelite is finely crystallized $(<2 \mu \mathrm{m})$. It was suspended in pure water in order to cover the $\mathrm{CaF}_{2}$ slide.

For FTIR analysis, clay and tobelite films were prepared by evaporation. Films of pure materials have been used rather than $\mathrm{KBr}$ mixtures to avoid $\mathrm{KBr}$-matrix interactions, water contamination and replacement of the $\mathrm{NH}_{4}$ of the clay by $\mathrm{K}$ from the matrix (Petit et al., 1999).

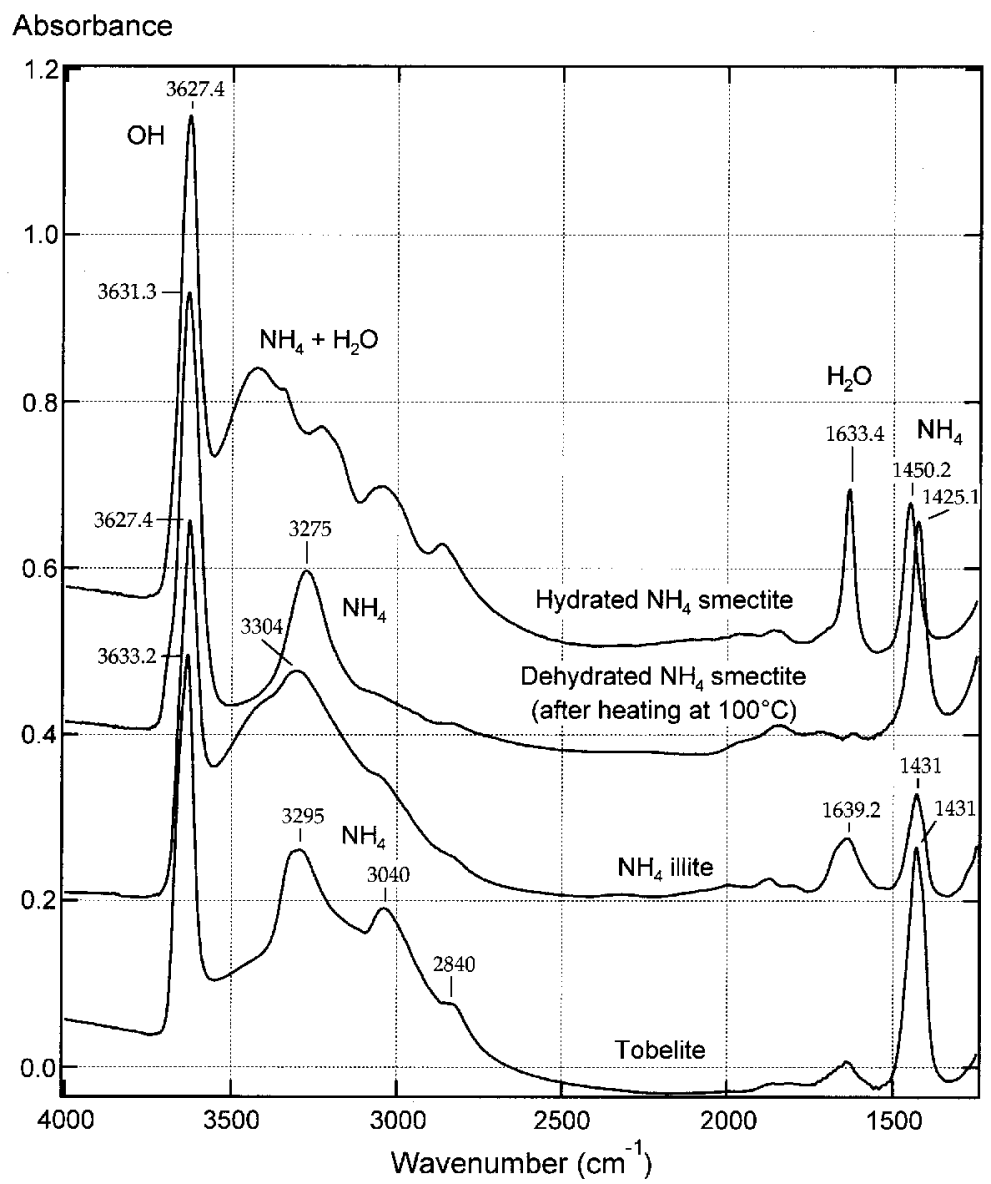

FIG. 1. FTIR spectra of hydrated $\mathrm{NH}_{4}$ smectite (equivalent to $P / P_{0}=1$ ), dehydrated $\mathrm{NH}_{4}^{+}$smectite (equivalent to $\left.P / P_{0}=0\right), \mathrm{NH}_{4}$-illite from The Netherlands, and tobelite, recorded at room temperature (except for the spectrum of dehydrated smectite acquired at $100^{\circ} \mathrm{C}$ ) with the IR microscope. 


\section{RESULTS}

Spectra of tobelite, illite and smectite were acquired at different temperatures to follow the effect of temperature on water bound directly to the $\mathrm{NH}_{4}^{+}$ cation and on IR band shapes. Absorption bands between 4000 and $600 \mathrm{~cm}^{-1}$ are assigned in Table 3. This study focuses preferentially on the $\mathrm{NH}_{4}^{+}$-bending vibration located between 1400 and $1500 \mathrm{~cm}^{-1}$ because in contrast with the stretching vibrations it is affected only a little by overlaps due to hydration water.

\section{FTIR spectra at room conditions}

Figure 1 shows IR spectra recorded at room conditions without any baseline correction. The only spectral treatment is the subtraction of atmospheric $\mathrm{CO}_{2}$ and $\mathrm{H}_{2} \mathrm{O}$. The spectrum corresponding to tobelite is characterized by a strong $\mathrm{NH}_{4}^{+}$-bending vibration centred at $1431 \mathrm{~cm}^{-1}$. This band displays some asymmetry towards low wavenumbers. A weak water-bending contribution is observed at $1630 \mathrm{~cm}^{-1}$. An $\mathrm{OH}$-stretching contribution from octahedral sheets is located at $3633 \mathrm{~cm}^{-1}$. Three main $\mathrm{NH}_{4}^{+}$-stretching bands are observed at 3295,3040 and $2840 \mathrm{~cm}^{-1}$. These bands are superimposed on the $\mathrm{O}-\mathrm{H}$-stretching vibrations of water (broad signals at 3620 and $3350 \mathrm{~cm}^{-1}$ in hydrated micas (Bishop et al., 1994)).

The illite spectrum is similar, with weaker $\mathrm{NH}_{4}$ bands and stronger water bands. A bending $\mathrm{H}_{2} \mathrm{O}$ band at $1639 \mathrm{~cm}^{-1}$ displays a marked asymmetry towards high wavenumbers, suggesting the presence of different types of adsorbed water.

The spectrum of hydrated $\mathrm{NH}_{4}$-smectite, recorded on a clay film just after water evaporation is characterized by water and $\mathrm{NH}_{4}^{+}$-bending vibrations of similar intensities and shapes. These two bands are sharp and symmetric. In the range corresponding to stretching $\mathrm{NH}_{4}$ and water vibrations, the shape of the spectrum is complex with numerous contributions.

\section{FTIR spectra at variable temperature}

Figure 2 shows the FTIR spectra of an $\mathrm{NH}_{4}$ smectite at 150,23 and $-180^{\circ} \mathrm{C}$ in the range corresponding to bending vibrations. At $150^{\circ} \mathrm{C}$, the bending band of water disappears and the $\mathrm{NH}_{4}^{+}$ bending band is shifted towards low wavenumbers with a maximum at $1425 \mathrm{~cm}^{-1}$ and a width at half

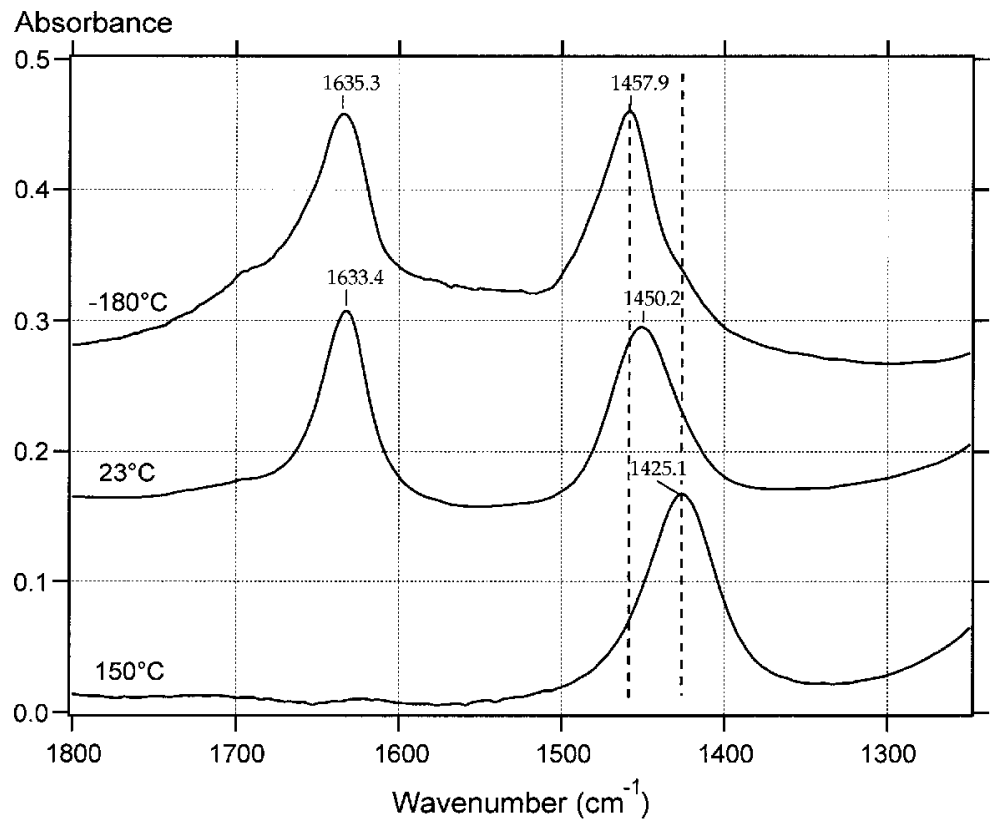

FIG. 2. FTIR spectra of the $\mathrm{H}_{2} \mathrm{O}$ - and $\mathrm{NH}_{4}^{+}$-bending vibrations of $\mathrm{NH}_{4}$ smectite recorded with the IR microscope at different temperatures. 
maximum (WHM) of $50 \mathrm{~cm}^{-1}$. The band seems perfectly symmetrical and can be fitted with a Lorentzian $(30 \%)+$ Gaussian $(70 \%)$ symmetric curve with a weak residual error. Smectite dehydration can also be observed in the valence region (Fig. 1) as the number of vibration bands in the $3600-3000 \mathrm{~cm}^{-1}$ range decreases (Fig. 1). One strong band is observed at $3275 \mathrm{~cm}^{-1}$. The $\mathrm{OH}$ stretching band is located at $3631 \mathrm{~cm}^{-1}$ with a shoulder at $3685 \mathrm{~cm}^{-1}$. At liquid nitrogen temperature, the $\mathrm{NH}_{4}$-bending band is narrowed (WHM = $40 \mathrm{~cm}^{-1}$ ) and centred at $1458 \mathrm{~cm}^{-1}$. A shoulder appears at $1430 \mathrm{~cm}^{-1}$. The water-bending vibration becomes non-symmetrical, but its maximum is only shifted by $2 \mathrm{~cm}^{-1}$.

The absolute intensities of both the stretching-OH band and $\mathrm{NH}_{4}$-bending band were measured for $\mathrm{NH}_{4}$-smectite from ambient to $400^{\circ} \mathrm{C}$ (Fig. 3). The integrated intensity of the $\mathrm{OH}$ band decreases sharply between 25 and $75^{\circ} \mathrm{C}$, remains stable up to $200^{\circ} \mathrm{C}$ and decreases slightly at higher temperatures. The integrated intensity of the $\mathrm{NH}_{4}$ band remains constant up to $200^{\circ} \mathrm{C}$ and then decreases with increasing temperature. Such evolutions are clearly observed by looking at the evolution of the band area ratio $\left(\mathrm{NH}_{4} / \mathrm{OH}\right)$ (Fig. 3).

The spectrum of tobelite was recorded at room temperature, $400^{\circ} \mathrm{C}$ and $-180^{\circ} \mathrm{C}$ (Fig. 4). At $400^{\circ} \mathrm{C}$ the $\mathrm{NH}_{4}$-bending vibration becomes symmetrical and shifts to $1419 \mathrm{~cm}^{-1}$. In the same way, the stretching band located at $3295 \mathrm{~cm}^{-1}$ shifts to $3280 \mathrm{~cm}^{-1}$ and the intensities of the stretching bands at 3040 and $2840 \mathrm{~cm}^{-1}$ decrease. At $-180^{\circ} \mathrm{C}$, the $\mathrm{NH}_{4}$ bending band contains three contributions at 1460,1433 and $1408 \mathrm{~cm}^{-1}$. Temperature lowering induces a narrowing of the absorption bands, which reveals these three contributions. However at such low temperature, ice crystals form on the preparation and their IR absorption bands partially mask the $\mathrm{NH}_{4}^{+}$-stretching area. The presence of ice also explains the weak band detected at $1650 \mathrm{~cm}^{-1}$ (Herzberg, 1947).

\section{FTIR spectra under controlled relative water pressure $\left(P / P_{0}\right)$}

The FTIR spectra of $\mathrm{NH}_{4}$-smectite under controlled temperature and water vapour relative pressures are presented in Fig. 5. The increase in $P / P_{0}$ is marked by the growth of the $\mathrm{H}_{2} \mathrm{O}$-bending vibration. The wavenumber of this band is shifted towards lower values at low $P / P_{0}(0.2)$ but remains
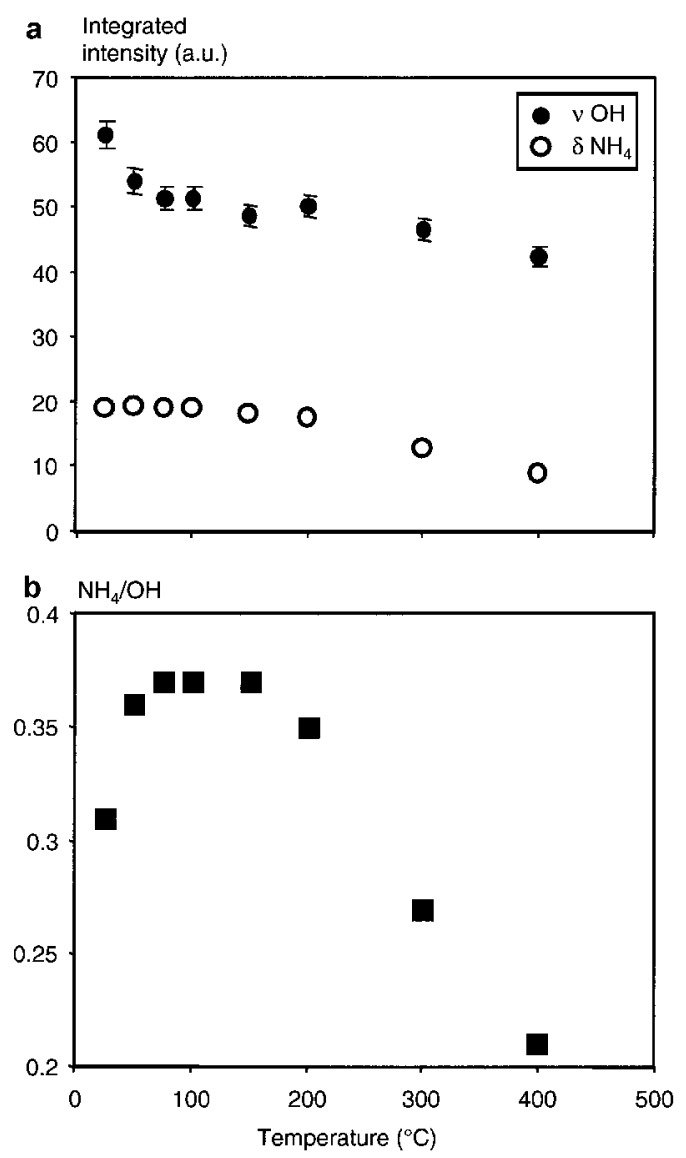

FIG. 3. (a) Evolution of the integrated intensities of the $\mathrm{OH}$-stretching band and the $\mathrm{NH}_{4}$-bending band of $\mathrm{NH}_{4}$ smectite with temperature. The error bars for the $\mathrm{NH}_{4}$ band integration are equivalent to the point size. (b) Evolution of the $\left(\mathrm{NH}_{4} / \mathrm{OH}\right)$ band area ratio with temperature.

constant at higher water pressure. The $\mathrm{NH}_{4}^{+}$-bending vibration is centred at $1425 \mathrm{~cm}^{-1}$ at $P / P_{0}=0$. It becomes asymmetrical with increasing water pressure with a shift of its position towards $1450 \mathrm{~cm}^{-1}$. The increase of background with increasing $P / P_{0}$ can be explained by the imperfect subtraction of the signal due to water vapour. These results can be combined with data derived from water adsorption gravimetry and XRD measurements under controlled water pressure (Fig. 6). When plotted as a function of the number of water molecules per interlayer cation the water adsorption and desorption isotherm exhibits three main domains $P / P_{0} \leqslant 0.25,0.25<P / P_{0}<0.6$ and $P / P_{0}>0.6$ (Fig. 6a). Such evolution is similar to 


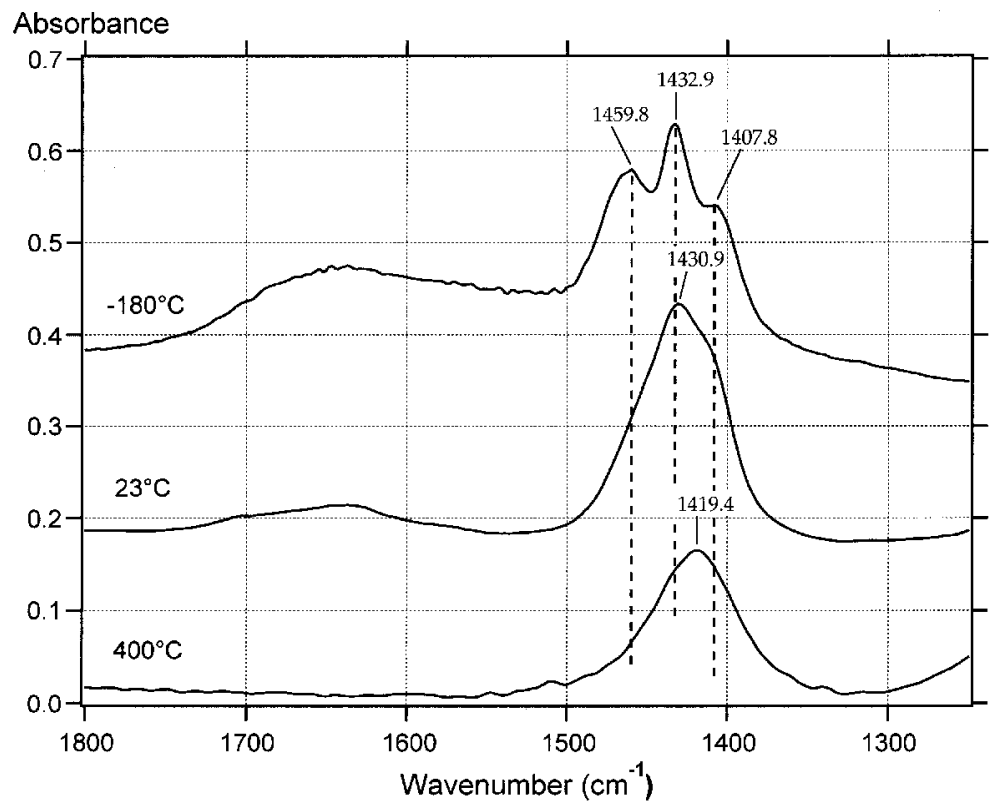

FIG. 4. FTIR spectra of the $\mathrm{NH}_{4}^{+}$-bending vibrations of tobelite recorded with the IR microscope at different temperatures.

the adsorption/desorption isotherm described for $\mathrm{K}$ smectite (Bérend et al., 1995). In the case of $\mathrm{K}$ montmorillonite, it was shown to correspond to one single type of site for $\mathrm{H}_{2} \mathrm{O}$ adsorption. The evolution of the (001) spacings with water pressure is presented in the middle part of Fig. 6. The evolution can be decomposed in three domains: for $P / P_{0} \leqslant 0.05$ the $d$ spacing does not change with water content; for $0.05<P / P_{0} \leqslant 0.3$, the $d$ spacing increases sharply to reach a value of $11.6 \AA$; and for $P / P_{0}>0.3$, the interlayer spacing increases slightly to reach a final value of $12.2 \AA$ at $P / P_{0}=$ 0.80 . The IR band area ratio $[1450 /(1450+1425)]$
(Fig. 6c) was calculated after decomposition of the $\mathrm{NH}_{4}$-bending vibrations in two main components. Water adsorption is marked by no change until a $P / P_{0}$ value of 0.07 , a strong increase of the [1450/ $(1450+1425)]$ IR band area ratio between 0.07 and 0.15 , a slight increase between 0.15 and 0.75 and then a strong increase up to 0.85 .

\section{DISCUSSION}

The FTIR analysis of $\mathrm{NH}_{4}$-smectites, illite and muscovite at variable temperature reveals clear differences in the profiles of the $\mathrm{NH}_{4}$-bending

TABLE 4. Symmetry group description for $\mathrm{NH}_{4}$ tetrahedra in layered minerals, described by analogy to $\mathrm{CH}_{4}-\mathrm{CH}_{3} \mathrm{D}-\mathrm{CH}_{2} \mathrm{D}_{2}$ molecules (Herzberg, 1947).

\begin{tabular}{cccc}
\hline $\begin{array}{c}\mathrm{NH}_{4} \\
\text { species }\end{array}$ & $T_{\mathrm{d}}$ & $\begin{array}{c}C_{3 \mathrm{v}} \\
\end{array}$ & $\begin{array}{c}C_{2 \mathrm{v}} \\
v_{1}\end{array}$ \\
$v_{2}$ & Wavenumber $\left(\mathrm{cm}^{-1}\right)$ & Wavenumber $\left(\mathrm{cm}^{-1}\right)$ & Wavenumber $\left(\mathrm{cm}^{-1}\right)$ \\
$v_{3}$ & $-(\mathrm{R})$ & $v_{1}(\mathrm{I}, \mathrm{R})$ & $v_{1}(\mathrm{R})$ \\
$v_{4}$ & $-(\mathrm{I}, \mathrm{R})$ & $v_{2}(\mathrm{I}, \mathrm{R})$ & $v_{2 \mathrm{a}}-v_{2 \mathrm{~b}}(\mathrm{R} ; \mathrm{R})$ \\
& $3275(\mathrm{I}, \mathrm{R})$ & $v_{3 \mathrm{a}}-v_{3 \mathrm{bc}}(\mathrm{I} ; \mathrm{I})$ & $v_{3 \mathrm{a}}-v_{3 \mathrm{~b}}-v_{3 \mathrm{c}}(\mathrm{R} ; \mathrm{I} ; \mathrm{I})$ \\
& $1400(\mathrm{I})$ & & $2840-3040-3295$ \\
& & $v_{4 \mathrm{a}}-v_{4 \mathrm{bc}}(\mathrm{I}, \mathrm{R} ; \mathrm{I}, \mathrm{R})$ & $v_{4 \mathrm{a}}-v_{4 \mathrm{~b}}-v_{4 \mathrm{c}}(\mathrm{I}, \mathrm{R} ; \mathrm{I} ; \mathrm{I}, \mathrm{R})$ \\
& & $1408-1433-1460$
\end{tabular}

I: IR active mode, R: Raman active mode 


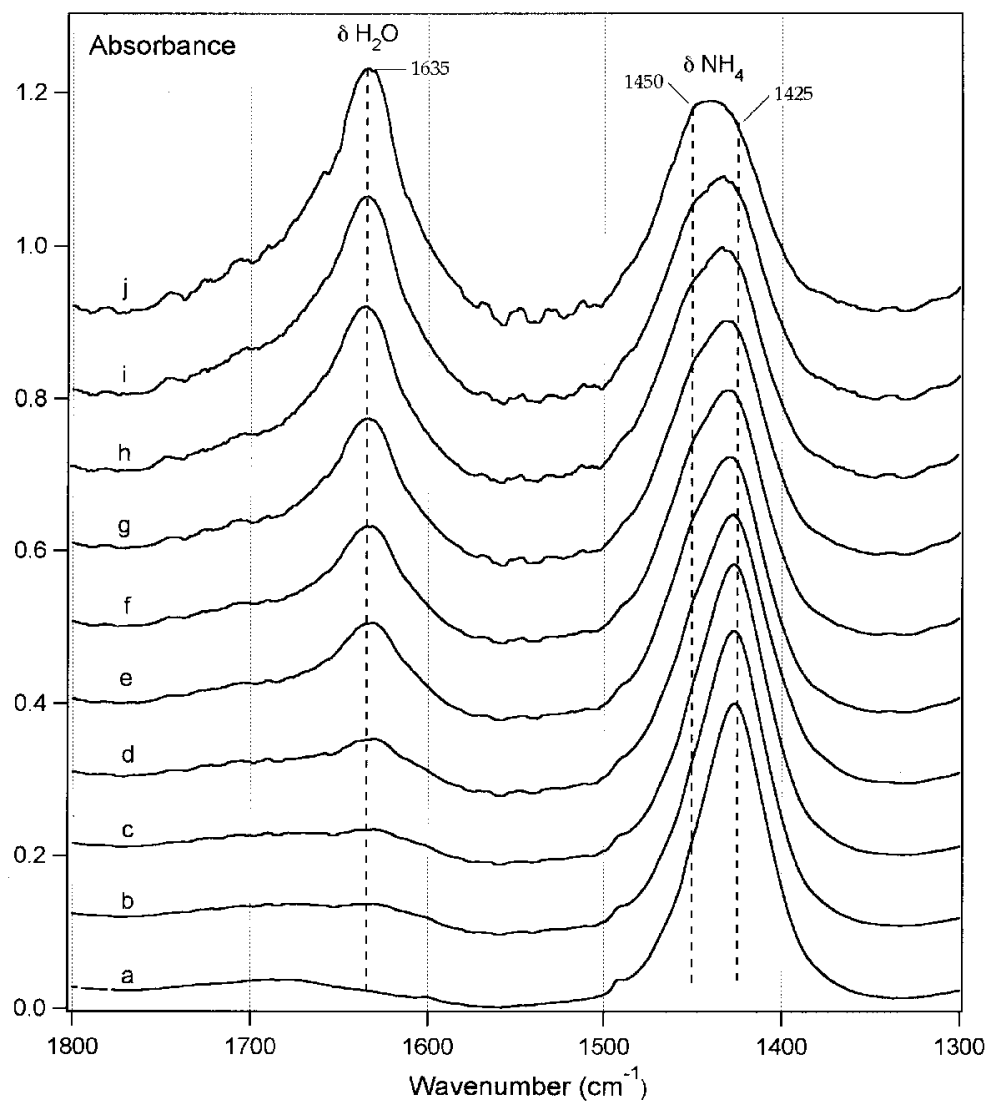

FIG. 5. FTIR spectra of the $\mathrm{H}_{2} \mathrm{O}$ - and $\mathrm{NH}_{4}^{+}$-bending vibrations of $\mathrm{NH}_{4}$ smectite acquired under water pressure control during the adsorption isotherm. $P / P_{0}=0$ (a), 0.024 (b), 0.039 (c), 0.099 (d), 0.174 (e), 0.249 (f), 0.402 $(\mathrm{g}), 0.601(\mathrm{~h}), 0.746(\mathrm{i})$ and $0.85(\mathrm{j})$.

vibrations. This band is symmetrical for smectite with a maximum located at $1450 \mathrm{~cm}^{-1}$ in hydrated conditions and at $1425 \mathrm{~cm}^{-1}$ for the dehydrated sample. Such a shift towards higher wavenumbers upon hydration is probably due to hydrogen bonding occurring between $\mathrm{NH}_{4}^{+}$ions and $\mathrm{H}_{2} \mathrm{O}$ molecules (Chourabi \& Fripiat, 1981). Hydrogen bonding could also explain the numerous bands observed in the $\mathrm{O}-\mathrm{H}-$ and $\mathrm{N}-\mathrm{H}$-stretching region of hydrated smectite. In the case of illite and tobelite, the $\mathrm{NH}_{4}$-bending vibration is composed of three bands centred at 1460,1433 and $1408 \mathrm{~cm}^{-1}$. The difference observed between smectite, illite and tobelite can be assigned to changes in the symmetry of the $\mathrm{NH}_{4}$ tetrahedron. In the interlayer space of smectite, $\mathrm{NH}_{4}$ interacts slightly with the tetrahedral sheet and has a $T_{\mathrm{d}}$ symmetry. Water adsorption around $\mathrm{NH}_{4}^{+}$cations does not induce any symmetry change but only a shift towards high wavenumbers.
For illite or tobelite, the $\mathrm{NH}_{4}$ tetrahedron is submitted to a different crystal field. The high negative charge defect in the tetrahedral sheet (mainly due to Al-for-Si substitution) involves a stronger attraction between TOT sheets and interlayer cations. The $\mathrm{NH}_{4}$ tetrahedron then loses its $T_{\mathrm{d}}$ symmetry, which is resolved into $C_{2 \mathrm{v}}$ symmetry as revealed by the presence of three $v_{3}$ and $v_{4}$ bands. This symmetry change is summarized in Table 4 where assignments are made by analogy with the $\mathrm{CH}_{4}$ molecule (Herzberg, 1947). The $T_{\mathrm{d}}-C_{2 \mathrm{v}}$ change thus appears as a good indicator for the smectite-illite transition.

Experiments with varying water pressures $\left(P / P_{0}\right)$ simulate the hydration phenomenon below the water saturation point. Water-saturated smectites are analysed at room conditions during heating experiments which correspond to natural smectites in geological stability conditions. Increasing $P / P_{0}$ 
induces a shift towards high wavenumbers of the bending vibration, but no change in the $\mathrm{NH}_{4}$ symmetry. At $P / P_{0}=0$, dehydration is not complete as the $[1450 /(1450+1425)]$ IR ratio is near 0.1 (Fig. 6), corresponding to a percentage of irreducible water of $10 \%$. Between $P / P_{0}=0$ and $P / P_{0}=$ 0.07 , both the IR ratio and the (001) spacing remain constant whereas the amount of adsorbed water increases. Such behaviour is related to the hydration of the external surfaces of clay particles. Between $P / P_{0}=0.07$ and $P / P_{0}=0.3$, both the $(001)$ spacing and IR ratio increase, which corresponds to the
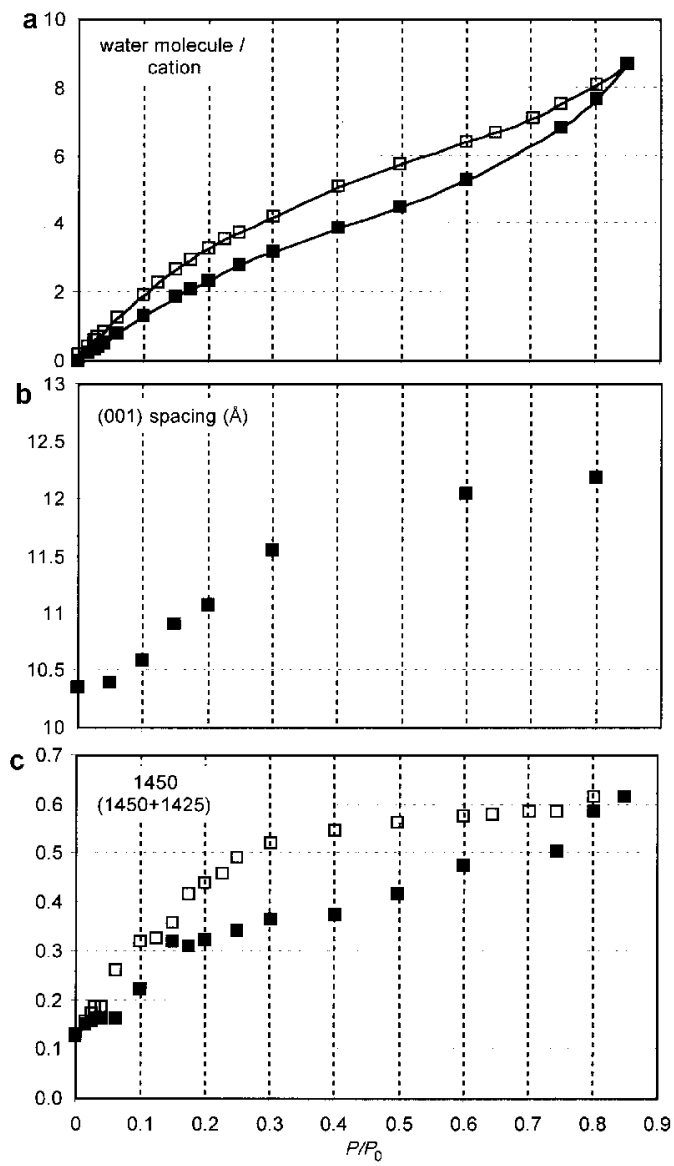

FIG. 6. (a) Water adsorption (filled squares) and desorption (open squares) isotherms expressed as the number of water molecules per $\mathrm{NH}_{4}^{+}$cation for the $\mathrm{NH}_{4}$ smectite. (b) Evolution of the (001) spacing for the $\mathrm{NH}_{4}$ smectite measured by XRD under controlled water pressure (adsorption branch). (c) Evolution with water relative pressure of the IR band area ratio $(1450 /(1450+1425))$ calculated after decomposition of the $\mathrm{NH}_{4}$-bending vibrations. opening of the sheets by hydration of some cations. As only two bands were detected by IR spectroscopy, this could indicate that hydration occurs cation by cation. No partial hydration of a cation is observed. Therefore, hydration of some interlayer spaces is enough to increase $d$ spacing. For $P / P_{0}$ between 0.3 and 0.75 , hydration regularly increases and opening of new interlayer spaces is rare as is shown by the slight increase in the $d$ spacing. For $P / P_{0}>0.75$, hydration drastically increases up to water saturation of the interlayer space and further to the destruction of clay particles.

The FTIR analysis of films of pure fine particles seems to be well adapted for $\mathrm{N}$ quantification inside $\mathrm{NH}_{4}$-bearing layered minerals. However, for a proper quantification, the $\mathrm{NH}_{4}$ environment must be taken into account, and therefore, hydration rate and/or charge balance have to be considered. The IR quantification procedure is based on a measurement of the ratio of the $\mathrm{NH}_{4}$ - and $\mathrm{OH}$-band areas that is correlated to the $\mathrm{NH}_{4}$ content. In that case, $\mathrm{OH}$ represents octahedral hydroxyls (two hydroxyls per half unit cell), and is thus proportional to the number of TOT sheets. Therefore, the $\mathrm{NH}_{4}$ content of minerals $\left(n_{\mathrm{NH}_{4}}\right)$ is proportional to the area ratio:

$$
n_{\mathrm{NH}_{4}}=k\left[\mathrm{NH}_{4}\right] /[\mathrm{OH}]
$$

Using calibrated reference samples, the value of $k$ has been determined at 0.8 for illite-muscovite and 1.1 for hydrated smectite.

Figure 3 reveals that for hydrated smectites, $\left[\mathrm{NH}_{4}\right] /[\mathrm{OH}]$ is less than for non-hydrated samples. This variation is due to the increase of the OH-band intensity with hydration. Such an increase is probably due to the presence of an absorption band assigned to free-water which superimposes on the absorption band of octahedral hydroxyls. Therefore, $\mathrm{N}$ quantification inside swelling minerals must take into account the hydration rate of $\mathrm{NH}_{4}$ cations and equation (1) becomes:

$$
n_{\mathrm{NH}_{4}}=\left(1.1\left[\mathrm{NH}_{4(1450)}\right]+0.9\left[\mathrm{NH}_{4(1425)}\right]\right) /[\mathrm{OH}]
$$

where $\left[\mathrm{NH}_{4(1450)}\right]$ and $\left[\mathrm{NH}_{4(1425)}\right]$ are the integrated intensities of the $\mathrm{NH}_{4}$-bending vibration centred at $1450 \mathrm{~cm}^{-1}$ and $1425 \mathrm{~cm}^{-1}$ after decomposition, and $[\mathrm{OH}]$ is the integrated intensity of the stretching vibration of hydroxyls. A $k$ value of 0.9 was determined for dehydrated smectite and is close to the value obtained for tobelite $(0.8)$. The difference between the two coefficients could be assigned to residual amounts of molecular water in the 'dehydrated' swelling clay. 
In the case of a good signal/background ratio, a detection limit of $\sim 300 \mathrm{ppm}$ of $\mathrm{N}$ can be expected. This detection limit is of the same order of magnitude as the detection limit of $100 \mathrm{ppm}$ provided by Schroeder and Ingall (1994). The $\mathrm{N}$ wt.\% in the reference $\mathrm{NH}_{4}$-smectite is 1.5.

\section{CONCLUSIONS}

Interlayer $\mathrm{NH}_{4}^{+}$cations can be used to characterize smectite and illite by FTIR spectroscopy. Our study shows that $\mathrm{Si}^{4+}-\mathrm{Al}^{3+}$ substitution induces a deformation of the $\mathrm{NH}_{4}$ tetrahedron marked by a symmetry change. $T_{\mathrm{d}}$ symmetry, with only one symmetric $\mathrm{NH}_{4}$-bending vibration, is lowered to $C_{2 \mathrm{v}}$ symmetry with a bending vibration consisting of three overlapping bands. No $C_{3 \mathrm{v}}$ symmetry has been detected in the studied dioctahedral minerals, contrary to what was suggested in previous works (Chourabi \& Fripiat, 1981; Casal et al., 1984). Using these results, a procedure for quantifying swelling $(s)$, and non-swelling ( $n s) \mathrm{NH}_{4}$-clays in mixtures (i.e. interstratified minerals) can be proposed: (1) water saturation of a clay deposit on a $\mathrm{CaF}_{2}$ slide; (2) IR measurement (spectrum A) and calculation of the $\left[\mathrm{NH}_{4}\right] /[\mathrm{OH}]$ band area ratio; (3) spectrum subtraction of a reference spectrum for tobelite (T) (i.e. A-T); (4) area measurements of $\mathrm{NH}_{4}$-bending and $\mathrm{OH}$-stretching vibrations, calculation of the $\left[\mathrm{NH}_{4}\right]_{s} /[\mathrm{OH}]_{s}$ band area ratio; (5) calculation of the $\left[\mathrm{NH}_{4}\right]_{n s} /[\mathrm{OH}]_{n s}$ band area ratio by $\left[\mathrm{NH}_{4}\right] /[\mathrm{OH}]-\left[\mathrm{NH}_{4}\right]_{s} /[\mathrm{OH}]_{s}$ subtraction; (6) estimation of the relative proportions of swelling and nonswelling $\mathrm{NH}_{4}$-minerals using the following calculations:

$$
\begin{gathered}
\% s=\frac{1.1\left[\mathrm{NH}_{4}\right]_{s} /[\mathrm{OH}]_{s} 100}{1.1\left[\mathrm{NH}_{4}\right]_{s} /[\mathrm{OH}]_{s}+0.8\left[\mathrm{NH}_{4}\right]_{n s} /[\mathrm{OH}]_{n s}} \\
\% n s=\frac{0.8\left[\mathrm{NH}_{4}\right]_{n s} /[\mathrm{OH}]_{n s} 100}{1.1\left[\mathrm{NH}_{4}\right]_{s} /[\mathrm{OH}]_{s}+0.8\left[\mathrm{NH}_{4}\right]_{n s} /[\mathrm{OH}]_{n s}}
\end{gathered}
$$

In addition, using such an analytical approach, dehydrated smectite can be distinguished from illite in the non-swelling clay minerals group.

Experiments with variable $P / P_{0}$ reveal that (1) hydration occurs cation by cation with no change of $\mathrm{NH}_{4}$ tetrahedron symmetry; (2) $10 \%$ of $\mathrm{NH}_{4}$ cations in smectite are surrounded by irreducible water; (3) good agreement is observed between FTIR and XRD measurements under varying water pressure.
Nitrogen quantification by FTIR does not require any complex sample preparation and so is well suited to routine analysis. However, in some cases, advanced sample and/or spectral treatments may be needed. Samples must be free of carbonate phases because of the overlapping between carbonatestretching and $\mathrm{NH}_{4}$-bending vibrations. The presence of other clay species besides smectite or illite must be considered and the influence of these additional species on the spectra must be suppressed by subtraction of their independently recorded spectra. Hydroxyl contribution from kaolinite or chlorite can be superimposed on hydroxyl bands from smectite-illite assemblages.

\section{ACKNOWLEDGMENTS}

TotalFinaElf supported this work. The authors wish to thank Dr S. Higashi from Koshi University, Japan, for providing the tobelite reference minerals, and Dr L. Michot for his very helpful review.

\section{REFERENCES}

Barth T., Rist K., Huseby B. \& Ocampo R. (1996) The distribution of nitrogen between bitumen, water and residue in hydrous pyrolysis of extracted Messel oil shale. Organic Geochemistry, 24, 889-895.

Bastoul A.M., Pironon J., Mosbah M., Dubois M. \& Cuney M. (1993) In-situ analysis of nitrogen in minerals. European Journal of Mineralogy, 5, $233-243$.

Bérend I., Cases J.M., François M., Uriot J.P., Michot L., Masion A. \& Thomas F. (1995) Mechanism of adsorption and desorption of water vapor by homoionic montmorillonites: 2. The $\mathrm{Li}^{+}, \mathrm{Na}^{+}, \mathrm{K}^{+}$, $\mathrm{Rb}^{+}$and $\mathrm{Cs}^{+}$-exchanged forms. Clays and Clay Minerals, 43, 324-336.

Bishop J.L., Pieters C.M. \& Edwards J.O. (1994) Infrared spectroscopic analyses on the nature of water in montmorillonite. Clays and Clay Minerals, 42, $702-716$.

Bos A., Duit W., Van Der Eerden A.M.J. \& Jansen B.H. (1988) Nitrogen storage in biotite: An experimental study of the ammonium and potassium partitioning between 1M-phlogopite and vapour at $2 \mathrm{~kb}$. Geochimica et Cosmochimica Acta, 52, $1275-1283$.

Boudou J.P., Mariotti A. \& Oudin J.L. (1984) Unexpected enrichment of nitrogen during the diagenetic evolution of sedimentary organic matter. Fuel, 63, $1508-1510$.

Casal B., Ruiz-Hitzky E. \& Serratosa J.M. (1984) Vibrational spectra of ammonium ions in crownether- $\mathrm{NH}_{4}^{+}$-montmorillonite complexes. Journal of 
the Chemical Society, Faraday Transactions 1, 80, $2225-2232$.

Chourabi B. \& Fripiat J.J. (1981) Determination of tetrahedral substitutions and interlayer surface heterogeneity from vibrational spectra of ammonium in smectites. Clays and Clay Minerals, 29, 260-268.

Eypert-Blaison C., Sauzéat E., Pelletier M., Michot L.J., Villiéras F. \& Humbert B. (2001) Hydration mechanism and swelling behavior of Na-magadiite. Chemistry of Materials, 13, 1480-1486.

Grishina S., Pironon J., Mazurov M., Goryainov S., Pustilnikov A., Fon-der-Flaas G. \& Guerci A. (1998) Organic inclusions in salt. Part 3: Oil and gas inclusions in Cambrian evaporite deposit (East Siberia). A contribution to the understanding of nitrogen generation. Organic Geochemistry, 28, $297-310$.

Herzberg G. (1947) IR and Raman Spectra. II Polyatomic molecules. Van Nostrand, New York.

Higashi S. (1982) Tobelite, a new ammonium dioctahedral mica. Mineralogical Journal, 11, 138-146.

Higashi S. (2000) Ammonium-bearing mica and mica/ smectite of several pottery stone and pyrophyllite deposits in Japan: their mineralogical properties and utilization. Applied Clay Science, 16, 171-184.

Hunt J.M. (1979) How gas forms. Pp. 150-185 in Petroleum Geochemistry and Geology. Freeman \& Co., San Francisco.

Lindgreen H. (1994) Ammonium fixation during illitesmectite diagenesis in Upper Jurassic shale, North Sea. Clay Minerals, 29, 527-537.

Morgan H.W., Staats P.A. \& Goldstein J.H. (1957) Infrared spectra of $\mathrm{N}^{15} \mathrm{H}_{3}$ and $\mathrm{N}^{15} \mathrm{H}_{4}^{+}$. Journal of Chemical Physics, 27, 1212.

Mortland M.M., Fripiat J.J., Chaussidon J. \& Uytterhoeven J. (1963) Interaction between ammonia and the expanding lattices of montmorillonite and vermiculite. Journal of Physical Chemistry, 67, $248-258$.

Nakamoto K. (1963) Infrared Spectra of Inorganic and Coordination Compounds, 2nd edition. Wiley, New York.

Pelletier M., De Donato P., Thomas F., Michot L. \& Cases J.M. (1999) Infrared spectroscopic study of water vapor adsorption by homoionic montmorillonites. The bending mode. Pp. 555-560 in: Clays for our Future, Proceedings of the 11th International Clay Conference (H. Kodama, A.R. Mermut \& J.C. Torrance, editors). Ottawa, Canada, 1997. Published by ICC97 Organizing Committee, Ottawa, Canada.

Petit S., Righi D., Madejová J. \& Decarreau A. (1999) Interpretation of the infrared $\mathrm{NH}_{4}^{+}$spectrum of the $\mathrm{NH}_{4}^{+}$-clays: application to the evaluation of the layer charge. Clay Minerals, 34, 543-549.

Pironon J., Pagel M., Lévêque M.H. \& Mogé M. (1995a) Organic inclusions in salt: Part 1: Solid and liquid organic matter, carbon dioxide and nitrogen species in fluid inclusions from the Bresse Basin (France). Organic Geochemistry, 23, 391-402.

Pironon J., Pagel M., Walgenwitz F. \& Barrès O. (1995b) Organic inclusions in salt: Part 2: Oil, gas and ammonium in inclusions from the Gabon margin. Organic Geochemistry, 23, 739-750.

Schroeder P.A. \& Ingall E.D. (1994) A method for the determination of nitrogen in clays, with application to the burial diagenesis of shales. Journal of Sedimentary Research, A64, 694-697.

Schroeder P.A. \& McLain A.A. (1998) Illite-smectites and the influence of burial diagenesis on the geochemical cycling of nitrogen. Clay Minerals, 33, $539-546$.

Shigorova T.A. (1982) The possibility of determining the ammonium content of mica by IR spectroscopy. Translation from Geokhimiya, 3, 458-462.

Šuchá V., Kraus I. \& Madejová J. (1994) Ammonium illite from anchimetamorphic shales associated with anthracite in the Zemplinicum of the western Carpathians. Clay Minerals, 29, 369-377.

Tissot B.P. \& Welte D.H. (1984) Petroleum Formation and Occurrence. Springer, Berlin.

Van der Marel H.W. \& Beutelspacher H. (1976) Atlas of Infrared Spectroscopy of Clay Minerals and their Admixtures. Elsevier, Amsterdam.

Vedder W. (1965) Ammonium in muscovite. Geochimica et Cosmochimica Acta, 29, 221 -228.

Williams L.B. \& Ferrell R.E. (1991) Ammonium substitution during maturation of organic matter. Clays and Clay Minerals, 39, 400-408.

Williams L.B., Ferrell R.E. Jr., Chinn E.W. \& Sassen R. (1989) Fixed-ammonium in clays associated with crude oils. Applied Geochemistry, 4, 605-616. 